\title{
How to MaKe PeEr FeedbaCk IN Teams USEFUl: AN EMPIRICAL STUDY
}

\author{
Thomas $\mathrm{O}^{\prime} \mathrm{Neill}^{1}$ and Nicoleta Maynard ${ }^{2}$ \\ ${ }^{1}$ Department pf Psychology, University of Calgary, Calgary, Canada \\ ${ }^{2}$ Faculty of Science and Engineering, Curtin University, Perth, Australia \\ toneill@ucalgary.ca,n.maynard@curtin.edu.au
}

\begin{abstract}
Evidence is clear that peer feedback has a slightly beneficial effect on future peer ratings of students effectiveness in teams, suggesting that peer feedback is useful. However, the effects are quite modest and are inconsistent. We believe one reason for this is the inconsistent approaches to debriefing and guiding the usage of peer feedback information. That is, instructors vary widely on the process they use to implement peer feedback in the classroom. Our feeling is that interventions that drive attention to and action on the results of the peer feedback will be instrumental for activating regulatory processes and creating stronger, more consistent behavior change. We report on one such intervention versus a control condition without any particular support beyond provision of the peer feedback scores and comments. We find that the intervention actually buffered students from scoring lower at a later time in the semester, suggesting that the intervention was successful in helping students maintain the early levels of positive ratings before the work became intensive and some members potentially failed to perform according to expectations.
\end{abstract}

Keywords: teamwork, peer feedback, accreditation, soft skills assessment, soft skills development, individual attributes

\section{INTRODUCTION}

Individual and Team Work is one of 12 Canadian Engineering Graduate Attributes identified by the Engineers Canada Accreditation Board (ECAB) as necessary for program accreditation [1]. For the past few years the Individual and Team Performance (ITP) Lab has been developing an assessment platform at ITPmetrics.com that provides students with automated peer feedback reports for learning and development. Indeed, peer feedback is being used extensively within student learning teams in engineering. For example, the Comprehensive Assessment of Team Member Effectiveness (CATME; [12]) has reached over 1 million users. Peer feedback in teams typically involves roundrobin quantitative ratings of teamwork behavior effectiveness as well as anonymous written qualitative feedback. Each member receives a report outlining the perceptions of his or her team members regarding teamwork behaviors and effectiveness.

In the current research we draw on empirical data from peer feedback gathered within ITPmetrics.com. ITPmetrics.com is a growing software system offering free research-backed team-based assessments, funded by the Canadian government (i.e., research grants). Almost 80,000 assessments have been taken to date at institutions in North America, Europe, and Australia. This database was used to investigate an intervention within a first-year engineering design course at Curtin University in Perth, Australia.

Feedback is a core tenet of virtually all theoretical models of learning and self-regulation [4; 5; 8]. Team members represent one of the obvious sources of feedback in student learning teams [2]. They interact with their team members and observe team member behavior more than any other source, and familiarity is needed for accuracy [13]. Moreover, feedback can offer an accountability mechanism that can reduce free riding [16] and enhance teamwork processes [7]. This may reduce the amount of time instructors spend resolving conflicts in teams by providing team members with an opportunity to share perceptions of behavior.

One of the big challenges has been identifying ways to make peer feedback more effective. Although it has been shown to have small effects [6], it is important to maximize the impact by ensuring students attend to the feedback, act on it, and are held accountable. Thus, we report on a multi-faceted intervention applied to one of two cohorts receiving peer feedback: an additional round of peer feedback, TA training on effective coaching practices for supporting their teams, and a final reflection assignment. 


\section{STUDY DESIGN}

\subsection{Sample}

There were two cohorts in this quasi-experimental design. In the first cohort, 410 students provided peer feedback of team member effectiveness after an initial project milestone and again before the end of the term (and final project milestone). This was done in the context of a first year engineering design course at Curtin University called Engineering Foundations: Principles and Communications.

In the second cohort, 204 students provided peer feedback of team member effectiveness after an initial project milestone, a mid-term project milestone, and again before the end of the term (and final project milestone). The intervention they received was three-pronged:

a. The mid-term assessment offered an additional opportunity to receive further peer feedback;

b. The teaching assistants received training at the beginning of term on a coaching approach to support the development of students' teamwork and interpersonal skills. During weekly workshops the TAs engaged students in dialogue about the project progress, used the skills of powerful questioning and listening to guide the students in setting out meaningful and achievable goals, and tracked the achievement of these goals and reflecting on their professional development.

c. A final reflection asked the students to reflect on their teamwork experience working through the project. The students used the peer feedback results completed during the semester and reflected on the way they implemented their goals and developed a pro-active plan for managing similar circumstances in the future.

\subsection{Survey}

Although several investigations on the measurement and dimensions of team member effectiveness have been advanced [e.g., 3; 14; 15], there appears to be one dominant model. This is the five dimensional framework identified by Loughry, Ohland, and Moore [11] and operationalized through the CATME. Their dimensions are (adapted terms used in ITPmetrics in parentheses): contributing to the team's work (commitment); strong foundation of knowledge, skills, and abilities (KSAs); interacting with teammates (communication); keeping the team on track, and expecting quality (emphasizing high standards). The dimensions were identified through a review of the teamwork literature, a review of existing peer evaluation forms used by instructors, thematic sorting of behaviors, subject-matter expert review, and multiple factor-analytic studies (as summarized by Loughry et al. [11]). Ohland et al. [12] offered additional reliability and validity evidence supporting these dimensions. The ITPmetrics.com application of these dimensions and a customized feedback report was made available in each student's dashboard following the rating period.

\section{RESULTS}

We found that the mean peer feedback scores went down from the first $(M=4.04, S D=.62)$ to the second $(M$ $=3.94, S D=.60)$ administration $(p<.05)$. The effect size using Cohen's $d$ for a standardized mean difference is .17, which is a small but non-trivial effect according to modern standards. Importantly, within this first cohort, no debrief or other information was provided to support the students in using the feedback to improve. Results suggest that without a supporting intervention, team members may discover over time that their peers are not as strong in teamwork as they perceived early on.

In the second cohort (the one receiving the intervention), we found that the mean peer feedback scores remained stable from the first $(M=4.13, S D=.56)$ to the second $(M=4.12, S D=.68)$ administration $(n s)$. In other words, there was no decrease at the final time period like in the first cohort (no intervention). Figure 1 contains the means for all time periods across cohorts $(\mathrm{Sem}=$ Cohort).

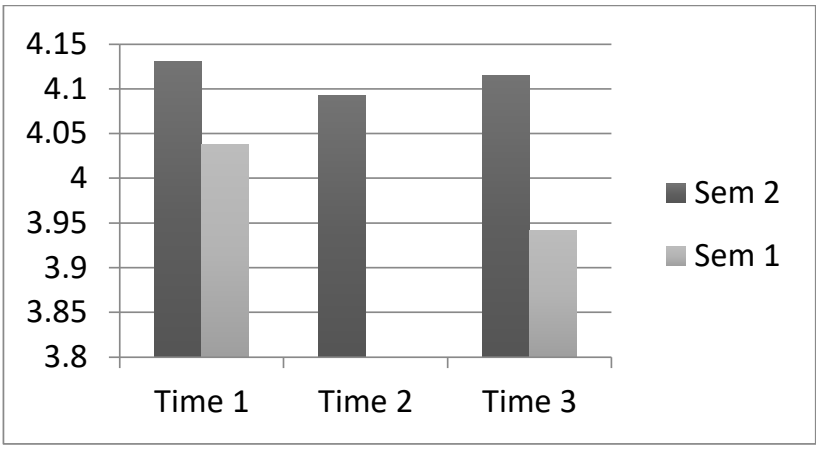

Figure 1: Semester 1 (i.e., cohort 1), Time 3 is significantly different from all other means.

\section{CONCLUSION}

Working effectively individually and as a member of a team is an essential skill as outlined by ECAB in their 12 Canadian Graduate Attributes necessary for program accreditation. It appears that the intervention offered a "buffering effect" that helped students develop their teamwork skills, such that when project deadlines neared and work became intensive, students were able to maintain their earlier effectiveness levels relative to those 
in cohort 1 (indeed, the final peer feedback administration scores were significantly higher for students receiving the intervention). We will share further details of the intervention during our presentation and offer materials that will help instructors apply the intervention in their own courses.

\section{References}

[1] Canadian Engineering Accreditation Board. "2016 accreditation criteria and procedures," Available as of 2016 from https://engineerscanada.ca/sites/default/files/accreditat ion-criteria-procedures- 2016-final.pdf

[2] Bamberger, P. A, "Competitive appraising: A social dilemma perspective on the conditions in which multiround peer evaluation may result in counterproductive team dynamics," Human Resource Management Review, vol. 17, pp. 1-18, 2007.

[3] Brutus, S., and Donia, M.B.L, "Improving the effectiveness of students in groups with a centralized peer evaluation system," Academy of Management Learning and Education, vol. 9, no. 4, pp. 652-662, 2010.

[4] Butler, D.L., and Winne, P.H, "Feedback and selfregulated learning: A theoretical synthesis," Review of Educational Research, vol. 65, no. 3, pp. 245-281, 1995.

[5] DeNisi, A.S., and Kluger, A.N, "Feedback effectiveness: Can 360-degree appraisals be improved?," Academy of Management Perspectives, vol. 14, no. 1, pp. 129-139, 2000.

[6] Donia, M. B. L., O’Neill, T. A., and Brutus, S, “The longitudinal effects of peer feedback in the development and transfer of student teamwork skills," Learning and Individual Differences, vol. 61, pp. 8798, 2018.

[7] Gabelica, C., Van den Bossche, P., Segers, M., and Gijselaers, W, "Feedback, a powerful lever in teams: A review," Educational Research Review, vol. 7, no. 2, pp. 123-144, 2012.

[8] Hattie, J., and Timperley, H, "The power of feedback," Review of Educational Research, vol. 77, no. 1, pp. 81-112, 2007.

[9] Jackson, C. L., Colquitt, J. A., Wesson, M. J., and Zapata-Phelan, C. P, "Psychological collectivism: A measurement validation and linkage to group member performance," Journal of Applied Psychology, vol. 91, pp. 884-899, 2006.

[10] Kozlowski, S. W., and Bell, B. S. Work groups and teams in organizations. New York: Wiley-Blackwell, 2003, 42 pp.

[11] Loughry, M.L., Ohland, M.W., and Moore, D.D, "Development of a Theory-Based Assessment of Team Member Effectiveness," Educational and
Psychosocial Measurement, vol. 67, no. 3, pp. 505524, 2007.

[12] Ohland, M.W., Loughry, M.L., Woehr, D.J., Bullard, L.G., Felder, R.M., Finelli, C.J., Layton, R.A., Pomeranz, H.R., and Schmucker, D.G, "The Comprehensive Assessment of Team Member Effectiveness: Development of a Behaviorally Anchored Rating Scale for Self- and Peer Evaluation." Academy of Management Learning and Education, vol. 11, no. 4, pp. 609-630, 2012.

[13] Paunonen, S. V., and O'Neill, T. A, "Self-reports, peer-ratings, and construct Validity." European Journal of Personality, vol. 24, pp. 189-206, 2010.

[14] Stevens, M.J., and Campion, M.A, "The knowledge, skill, and ability requirements for teamwork: Implications for human resource management," Journal of Management, vol. 20, no. 2, pp. 503-530, 1994.

[15] Taggar, S., and Brown, T.C, "Problem-solving team behaviors: Development and validation of BOS and a hierarchical factor structure," Small Group Research, vol. 32 , no. 6 , pp. 698-726, 2001.

[16] Taras, V., Steel, P., O’Neill, T. A., Tullar, W., and McLarnon, M, "Free-Riding in Global Virtual Teams: An Experimental Study of Antecedents and Strategies to Minimize the Problem," Paper presented at the annual meeting of Academy of International Business, (New Orleans, USA; 27-30 June, 2016), 2016.

[17] Willey, K., and Freeman, M. (2006). Completing the learning cycle: The role of formative feedback when using self and peer assessment to improve teamwork and engagement. in Proceedings of the 17th Annual Conference of the Australasian Association for Engineering Education: Creativity, Challenge, Change; Partnerships in Engineering Education (p. 751). Australasian Association for Engineering Education. 